\title{
KARAKTER DANAU LAUT BALBULLOL DI MISOOL RAJA AMPAT
}

\author{
Marine Lake Balbullol Character at Misool Raja Ampat \\ Gandi Y.S. Purba ${ }^{1,2 *}$, Eko Haryono ${ }^{1}$, Sunarto ${ }^{1}$ \\ ${ }^{1}$ Fakultas Geografi, UGM, Bulak Sumur, Yogyakarta, 55281 Indonesia \\ ${ }^{2}$ Jurusan Ilmu Kelautan, FPIK, UNIPA, Manokwari, 98314 Indonesia \\ *Korespondensi: gandi.yantri@mail.ugm.ac.id, gyspurba@gmail.com
}

\begin{abstract}
ABSTRAK
Danau laut adalah ekosistem unik yang ditemukan terfokus hanya di empat lokasi di dunia, salah satunya di Raja Ampat. Diantara kepulauan karst di Misool, Raja Ampat selatan, danau laut dapat dijumpai. Danau-danau tersebut memiliki karakter yang unik sesuai tingkat koneksinya dengan laut. Danau Balbullol adalah danau yang paling dalam diantara danau laut di Misool, terasing, dan belum pernah dikaji. Melalui studi ini ingin mengetahui karakter dari Danau Balbullol. Deskripsi danau dilakukan dengan serangkaian survei lapangan dan perekaman logger untuk mengetahui karakter fisik, kualitas air, dan kehadiran biota. Hasilnya diketahui luas danau adalah 1,94 ha dengan kedalaman maksimum $38 \mathrm{~m}$. Suhu dan salinitas memperlihatkan profil vertikal yang homogen, sehingga membentuk tipe danau holomiktik. Selama 6 bulan rekaman logger, menunjukan suhu di danau selalu lebih panas dari pada di laut, demikian juga salinitas yang lebih salin di danau. Pasut di danau tertunda 4 jam daripada laut, walaupun jarak antara danau dan laut sangat dekat $(<45 \mathrm{~m})$. Amplitudo pasut hanya 25\% daripada laut. Berdasarkan karakter pasut ini, Danau Balbullol merupakan danau yang terisolasi, namun tidak ditemukan biota sebagai indikator danau terisolasi. Ditemukan minimal 7 karang lunak dengan atribut banyak dan melimpah mendiami danau ini.
\end{abstract}

Kata kunci: Danau laut, Misool, Raja Ampat, Mastigias sp., Anchialine

\begin{abstract}
Marine lake is a unique ecosystem. It focuses at four locations in the world, one of them is in Raja Ampat. Among karst islands at Misool, south Raja Ampat, marine lakes may found. Each lake have a unique character according to the level of connection with the sea. Lake Balbullol is the deepest lake from the sea lakes in Misool, alienated, and has never been studied. This study want to know the character of Lake Balbullol. Description of the lake was done by a series of field surveys and loggers recording to determine the physical character, water quality, and presence of the biota. Lake's width was 1.94 ha and the maximum depth was $38 \mathrm{~m}$. Temperature and salinity showed a homogeneous vertical profile, thus forming a holomictic type. During 6 months recording, the temperature was always warmer than at the ocean, as well as salinity. Although the distance between the lake and the sea is very close $(<45 \mathrm{~m})$, the tide on the lake was delayed 4 hours rather than the sea. Tidal amplitude was only $25 \%$ of the ocean. From these tide characters, Lake Balbullol was isolated lakes, however, there were no biota as an indicator of isolated lakes exist. There were at least 7 soft corals with attributes many and abundant exist in this lake.
\end{abstract}

Key words: Marine lake, Misool, Raja Ampat, Mastigias sp., Anchialine 


\section{PENDAHULUAN}

Danau anchialine adalah badan air yang keseluruhan dikelilingi oleh daratan dan sangat bervariasi pada bentuk, ukuran dan jarak dari laut. Istilah yang paling lazim adalah danau laut. Holthuis (1973) mengartikan anchialine adalah genangan tanpa koneksi permukaan dengan laut, terdiri dari air asin atau payau dan berfluktuasi karena pasut.

Terdapat sekitar 200 danau laut di dunia yang terkonsentrasi di Bahamas, Palau, Vietnam dan Indonesia (Dawson dkk. 2009). Lokasi-lokasi ini memiliki karakteristik karst semi-submerged terhadap laut. Di Raja Ampat baru diketahui sekitar 55 danau laut, 15 diantaranya terdapat di Wayag dan Gam, dan 40 lainnya di Misool (Becking dkk. 2009; Becking dkk. 2014).

Kajian tentang danau laut dimulai di Palau dan sampai sekarang masih menjadi lokasi riset terbanyak tentang danau laut. Awal penelitian danau laut di Palau dilakukan oleh Hamner dkk. (1982) yang menulis tentang karakteristik Danau Ubur-ubur, yang meliputi karakter fisik, kimia, dan biologi. Kemudian oleh peneliti yang sama penelitian berlanjut ke tiga belas danau terstratifikasi yang lain di Palau. Danau stratifikasi adalah tipe danau yang tidak lazim ditemukan di daerah tropis namun sesuatu yang menarik karena semua ubur-ubur yang merupakan maskot beberapa danau hanya ditemukan di danau statifikasi. Hamner and Hamner (1998) menjelaskan kondisi tersebut dapat terjadi karena beberapa faktor spesifik yang ada di lokasi danau tersebut.

Di Raja Ampat penelitian tentang danau laut telah dilakukan oleh Becking dkk. (2011). Sebelumnya, Becking dkk. (2009) telah melakukan serangkaian survei udara untuk mendeteksi keberadaan danau laut. Di Misool, Becking dkk. (2014) melaporkan ditemukannya tiga danau laut yang dihuni oleh ubur-ubur. Salah satunya adalah Danau Lenmakana yang sekarang ramai dikunjungi wisata- wan. Bahkan setahun terakhir telah berdiri dua buah homestay di pantai sebelum masuk ke Danau Lenmakana.

Danau Balbullol terletak paling timur semenanjung Kaunutklolo. Berbeda dengan Danau Lenmakana yang merupakan objek wisata, Danau Balbullol adalah danau yang minim kunjungan wisata. Hanya segelintir orang yang pernah sampai di danau ini. Danau Lenmakana telah lebih dahulu mendapat tekanan kunjungan wisatawan sebelum diketahui karakter alamiah danau ini. Padahal ekosistem danau laut adalah ekosistem yang sangat sensitif terhadap pengaruh manusia maupun alam. Melalui kajian di Danau Balbullol akan dideskripsikan karakter danau yang meliputi aspek fisik, kualitas air, dan biota sebagai pangkalan data kondisi alami danau. Data ini berguna untuk pengelolaan danau agar dalam pemanfaatannya dapat memiliki tolak ukur untuk mengontrol eksploitasi berlebihan danau laut di Misool.

\section{METODE PENELITIAN}

\section{Lokasi Penelitian}

Penelitian ini dilakukan di Danau Balbullol, yang terletak di pulau Misool sebelah Tenggara (Gambar 1). Misool Tenggara adalah Konservasi Laut Daerah (KKLD) yang memiliki luas 343,200 ha berdasarkan Perbup No. 66/2007, Perda No. 27/2008, dan Perbup No. 5/2009 (Mangubhai dkk. 2012).

\section{Metode Pengumpulan data}

\section{Morfometri dan Kedudukan Danau}

Morfometri danau didapatkan dengan cara pemeruman. Untuk mengukur kedalaman cara yang digunakan adalah dengan mengumpulkan data kedalaman sebanyak-banyaknya dari titik-titik pemeruman. Hal ini dilakukan karena menetapkan lajur pemeruman yang rapat dan konsisten sulit dilakukan di lapangan karena sarana apung yang digunakan adalah pelampung tidak bermesin. 


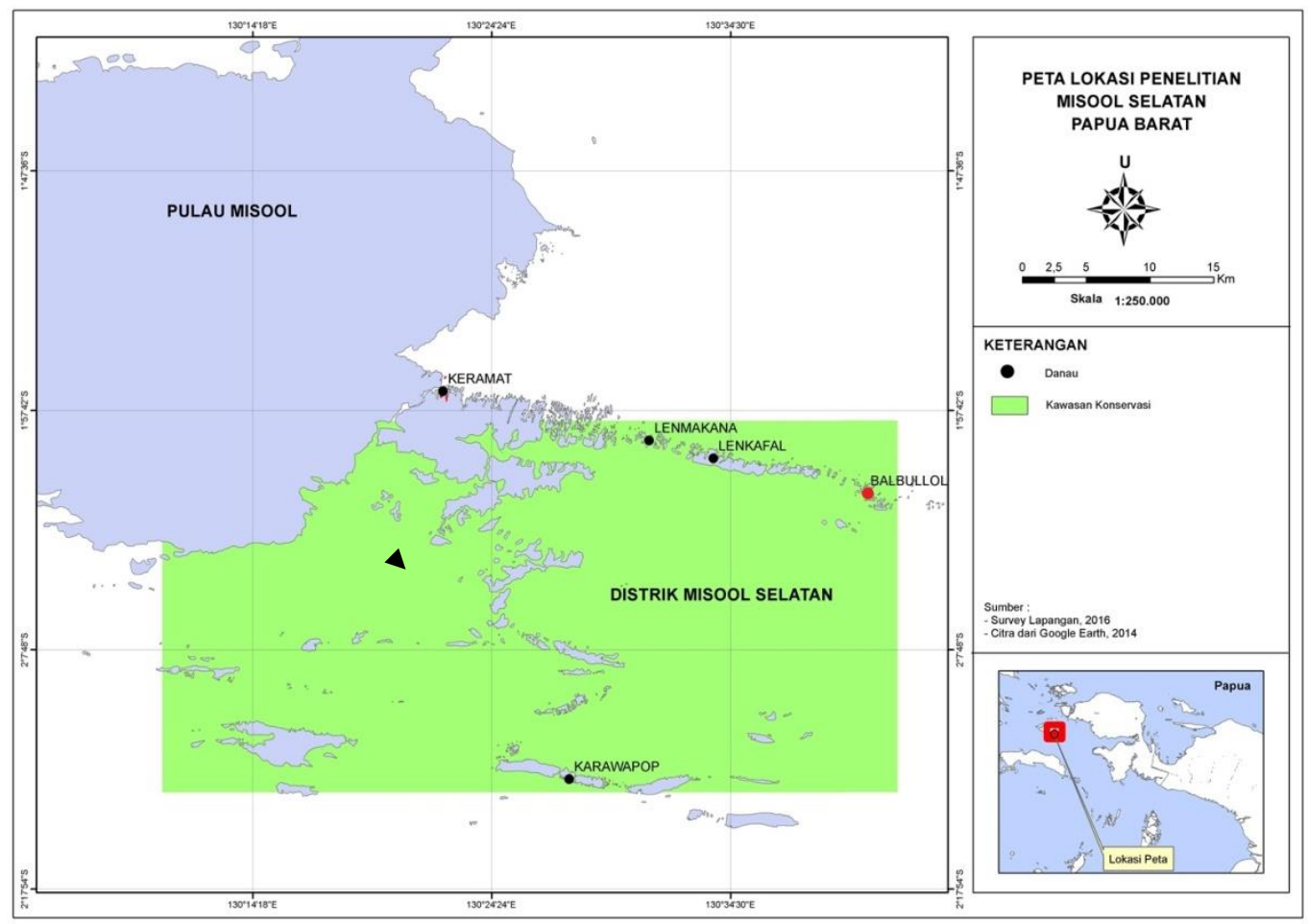

Gambar 1. Lokasi Danau Balbullol

Pelampung ini sangat dipengaruhi oleh aliran arus dan angin. Penetapan lajur sederhana dilakukan dengan membagi danau menjadi dua bagian dengan lajur yang berbeda pada saat kembali ke titik awal. Dengan demikian luasan danau akan mendapat empat lajur. Aplikasi OSM Tarcker untuk Android sangat membantu untuk mendapatkan bentuk danau dengan cara mengelilingi danau. Kedalaman danau juga diukur saat mengelilingi danau. Setelah nilai $\mathrm{x}, \mathrm{y}, \mathrm{z}$ yang merupakan lintang, bujur dan kedalaman didapatkan, selanjutnya kumpulan nilai diplotkan dengan bantuan perangkat lunak ArcGIS 10.1.

\section{Parameter Kualitas Air Danau}

Parameter suhu dan salinitas vertikal didapatkan dengan menggunakan logger konduktivitas yang diikat di kawat stainless berpemberat. Kawat ini akan diulur ke dalam air per satu meter. Bersamaan dengan itu logger akan turut merekam. Pengukuran dilakukan di 3 titik danau, sebelah utara, tegah, dan selatan. Data suhu dan salinitas dipasangkan dengan data kedalaman hingga menampilkan profil vertikal suhu dan salinitas.

Parameter kualitas air insitu menggunakan alat multimeter, yakni mengukur keasaman dengan menggunakan $\mathrm{pH}$ meter Hana Instruments $\mathrm{HI}$ 9025, suhu dan Oksigen terlarut menggunakan YSI 550A, dan salinitas menggunakan Atago hand-held refractometer.

\section{Data Rangkaian Waktu}

Data rangkaian waktu yang diukur meliputi data muka air laut, suhu, dan salinitas. Parameter ini diukur dengan menggunakan logger, yakni logger muka air HOBO U20L dan logger konduktivitas HOBO U24-002-C (Gambar 2). Kedua logger ini dipasang di danau, laut, dan udara. Penggikatan logger di danau dan laut dilakukan di bawah permukaan air, tetap terendam ketika surut terendah. Di danau pada kedalaman $2 \mathrm{~m}$ dan di laut pada kedalaman 3,5 m. Logger di udara diikat setinggi $5 \mathrm{~m}$. Logger di laut dan di udara diikat di Kampung Harapan Jaya sebagai tempat logistik. Kemudian data series danau dan laut diplotkan di grafik. 
Perbandingan antara grafik danau dan laut ataupun fluktuasi grafik di masingmasing danau atau laut akan memperlihatkan perbedaan keduanya. Terdapat juga analisis statistika sederhana yang meliputi nilai maksimum, minimum, mean, dan standar deviasi.

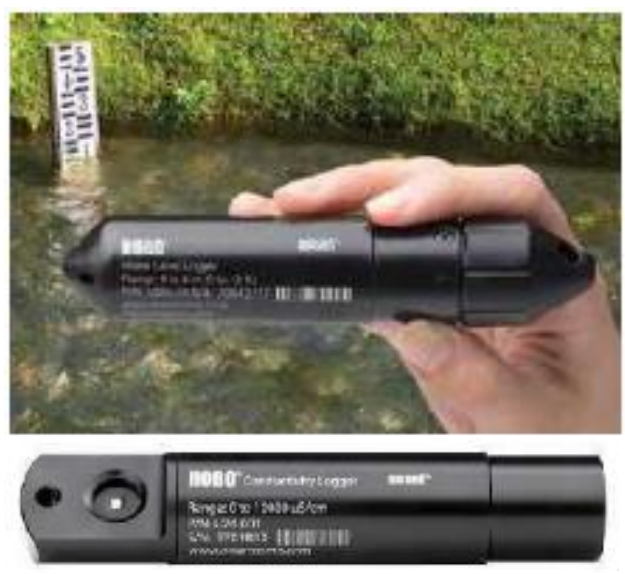

Gambar 2. Logger muka air HOBO U20L dan konduktivitas HOBO U24002-C

Mendapatkan nilai fluktuasi pasut perjamnya yakni dengan cara mengurangi nilai minimal dari keseluruhan data muka air dengan masing-masing nilai muka air.

\section{Biota}

Semua flora dan fauna di danau diamati, diidentifikasi, dan didokumentasi. Identifikasi menggunakan bantuan laporan survei sebelumnya di Palau, Kakaban, Vietnam dan situs identifikasi online. Pengamatan biota hanya secara visual. Dinding vertikal terendah sebelum mencapai danau berbatasan langsung dengan air danau, hingga tidak memungkinkan menggunakan kuadran dan menghitung individu biota. Biota diberikan atribut sedikit, sedang, banyak dan berlimpah. Sedikit berarti biota terlihat hadir di danau. Sedang berarti biota lebih mudah terlihat di berbagai bagian danau. Banyak berarti biota sering terlihat di banyak bagian danau. Melimpah berarti biota terlihat mendominasi di seluruh bagian danau.

\section{HASIL DAN PEMBAHASAN}

Danau Balbullol berada pada $02^{\circ} 01 \mathrm{~S} 130^{\circ} 40^{\prime} \mathrm{BT}$, terletak di ujung paling timur Semenanjung Kaunutlol. Dari mulai pintu masuk sampai mencapai danau, batuan karst sangat terjal dan curam. Walaupun tergolong sulit dan harus sangat hati-hati, jarak tempuh dari pintu masuk sampai di danau hanya memakan waktu sekitar 10 menit. Gambar 3 adalah panorama Danau Balbullol.

Hubungan dengan laut terjadi secara periodik bersamaan dengan pasut. Di saat pasang atau surut air akan masuk atau keluar melalui saluran-saluran penghubung berupa pori, lubang, dan rekahan (Gambar 4). Tidak ditemukan gua permukaan atau terusan.

Karakter Danau Balbullol dirangkum pada Tabel 1 untuk kemudian diuraikan pada pembahasan selanjutnya.

Tabel 1. Karakter Danau Balbullol

\begin{tabular}{|c|c|}
\hline Parameter & \\
\hline Posisi & $02^{\circ} 01 \mathrm{~S} \quad 130^{\circ} 40^{\prime} \mathrm{BT}$ \\
\hline Jarak terdekat dg laut & 44,63 \\
\hline Luas (ha) & 1,94 \\
\hline Kedalaman mak. (m) & 38,00 \\
\hline Rata-rata suhu insitu $\left({ }^{\circ} \mathrm{C}\right\}$ & 27,37 \\
\hline Rata-rata salinitas insitu (ppt) & 32,50 \\
\hline DO & 9,42 \\
\hline PH & 7,35 \\
\hline Tertundanya pasut & 3-4 jam \\
\hline Koneksi & pori, lubang, rekahan \\
\hline
\end{tabular}




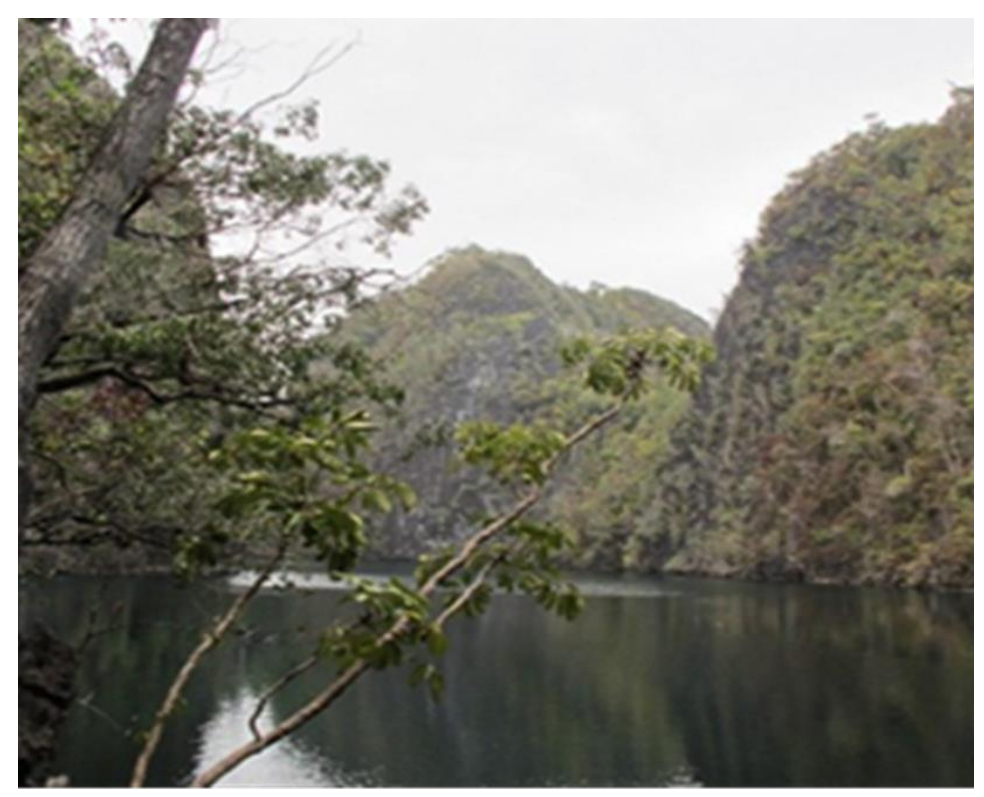

Gambar 3. Panorama Danau Balbullol

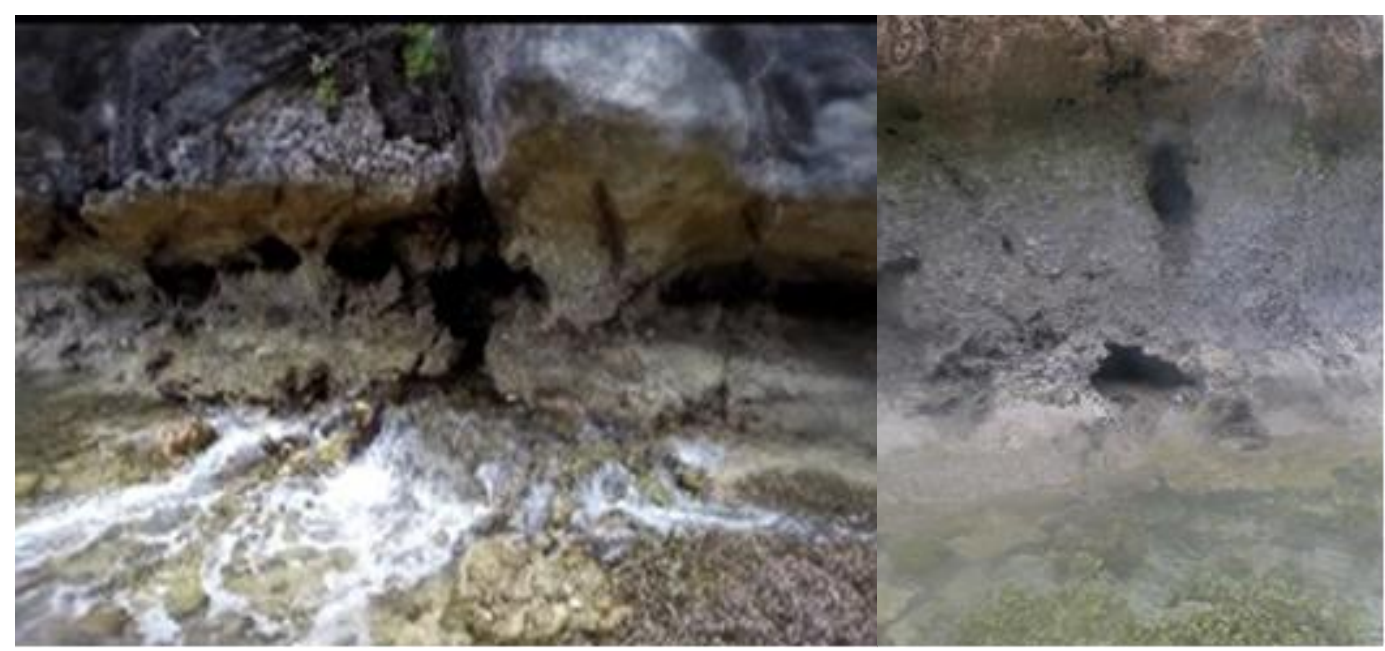

Gambar 4. Air yang mengalir ke luar danau ketika surut

\section{Waktu terbentuknya Danau Balbullol}

Colin (2009) menyatakan formasi danau erat hubungannya dengan kenaikan muka laut. Danau yang lebih dalam adalah danau yang lebih dulu tergenang air. Kedalaman maksimum Danau Balbullol adalah $38 \mathrm{~m}$ (Gambar 5). Artinya danau di Misool berumur lebih muda daripada di Palau, dimana danau terdalam ditemukan 60 m, yakni Lake Tketau. Danau ini mulai terbentuk kira-kira 12.000 tahun yang lalu, sedangkan yang lebih dangkal kirakira 4.000-5.000 tahun yang lalu. Untuk sementara, Danau Balbullol adalah danau terdalam dari semua danau di Misool (Purba dkk, 2017). Jadi danau di Misool dengan kedalaman $38 \mathrm{~m}$, menurut umur geologi masih lebih muda dari pada di Palau. Purba dkk (2017) memperkirakan Danau Balbullol berumur dan mulai terisi semenjak 9.250 tahun yang lalu. Selanjutnya setelah $9.250 \mathrm{BP}$ muka air terus naik mengisi bagian-bagian yang cekung yang lebih dangkal lainnya. 


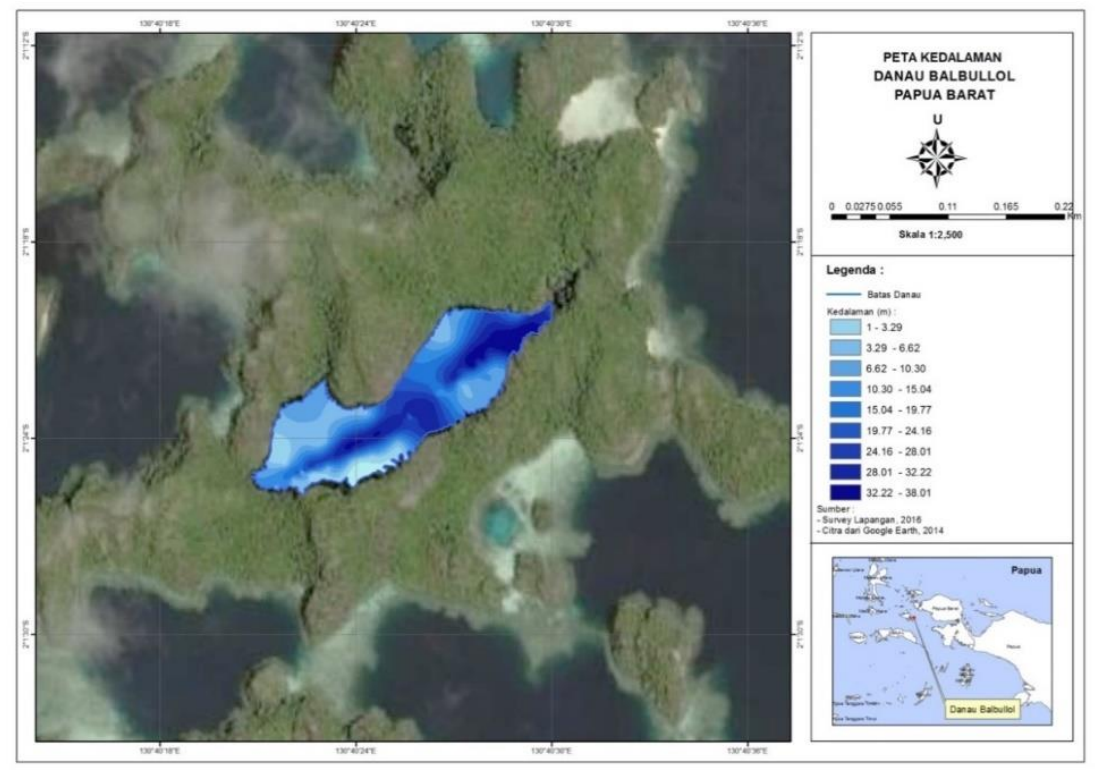

Gambar 5. Peta kedalaman Danau Balbullol

\section{Kualitas Air}

\section{Profil Suhu dan Salinitas}

Pengukuran profil vertikal danau pada Gambar 6 memperlihatkan suhu menurun dengan bertambahnya kedalaman. Kondisi sebaliknya terjadi untuk salinitas. Perubahan suhu dan Sali-nitas yang sedikit ini hanya disebabkan oleh pengaruh atmosfer terhadap permu-kaan danau. Selanjutnya parameter men-jadi homongen sampai ke dasar sehingga Danau Balbullol bertipe holomiktik. Di wilayah tropis, danau holomiktik memang lazim ditemukan karena tidak ada penga- ruh pergantian cuaca ekstrim seperti di wilayah subtropis. Namun di Palau, dari 57 danau laut, ditemukan 12 danau laut yang bertipe meromiktik (Hamner dan Hamner, 1998). Ada beberapa faktor pendukung yang saling mendukung, diantaranya tingginya curah hujan pertahun (3000-3500 mm/th), sebagian besar danau dikelilingi oleh mangrove hingga akarnya memperkecil percampuran oleh pasut, dan adanya percampuran di kedalaman tengah karena ada arus pasut yang kuat masuk ke danau (Hamner dan Hamner, 1998). Kondisi ini tidak ditemukan di danau laut Danau Balbullol.

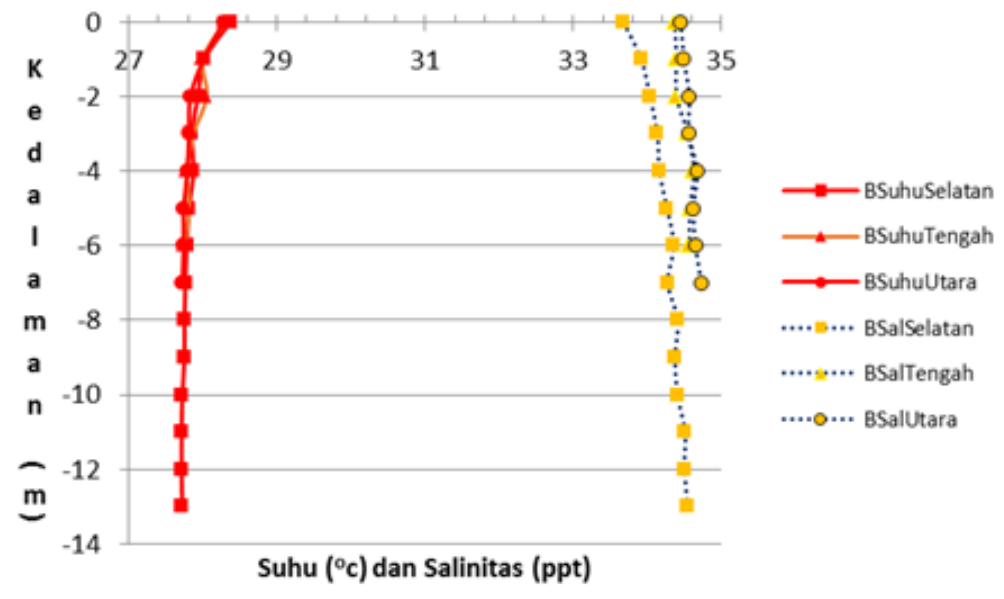

Gambar 6. Profil vertikal dari Suhu dan Salinitas di Danau Balbullol 


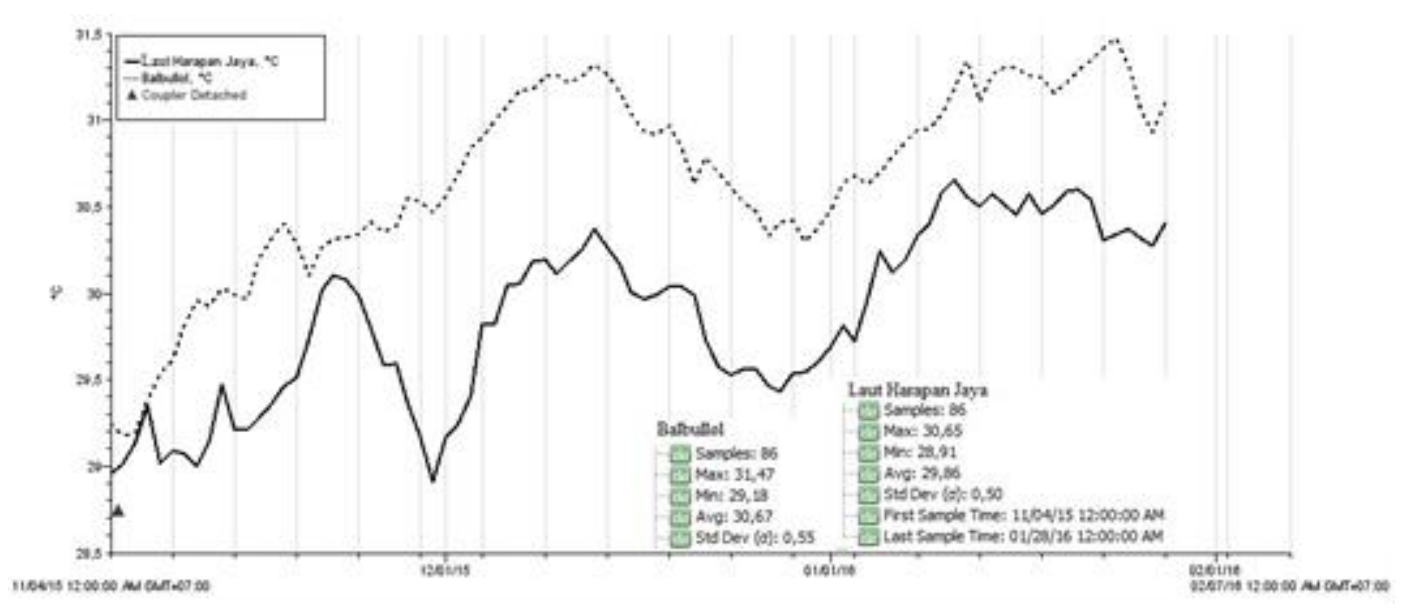

Gambar 7. Time series suhu di laut Harapan Jaya dan Danau Balbullol. Logger di pasang di kedalaman 3,5 $\mathrm{m}$ dan $2 \mathrm{~m}$

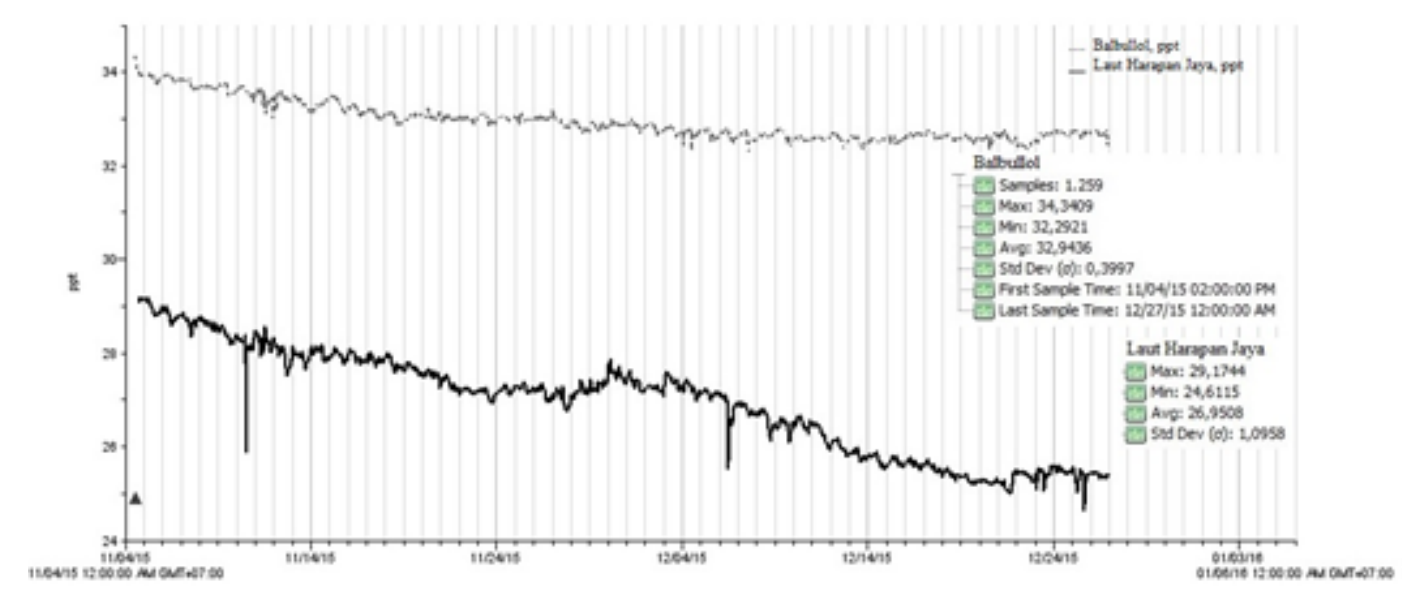

Gambar 8. Time series salinitas di Laut Harapan Jaya dan Balbullol Logger di pasang di kedalaman 3,5 $\mathrm{m}$ dan $2 \mathrm{~m}$

Data series suhu dari perekaman 6 bulan menujukkan suhu di Danau Balbullol lebih panas $1^{\circ} \mathrm{C}$ daripada di laut. Danau yang berbentuk basin dangkal akan lebih mudah panas ataupun dingin. Namun demikian keduanya memiliki pola time series yang hampir sama. Artinya, air di dalam danau adalah air yang berasal dari laut, yang mengalami pemanasan sesuai dengan kondisi di danau.

Salinitas di Danau Balbullol lebih tinggi daripada di laut (Gambar 8). Salinitas sangat stabil dengan fluktuasi dari nilai rata-rata hanya 0,3 ppt. Salinitas di laut pada awal November sampai akhir
Januari berkurang hingga 3 ppt karena tingkat presipitasi meningkat dengan adanya musim penghujan di wilayah Raja Ampat.

\section{Tinggi Muka air}

Tipe pasut di perairan Indonesia timur secara luas dan perairan Misool khususnya adalah pasut bertipe ganda campuran. Terjadi dua kali pasang dan surut dalam sehari, dengan tinggi puncak pasang atau lembah surut yang tidak sama (Gambar 9). 


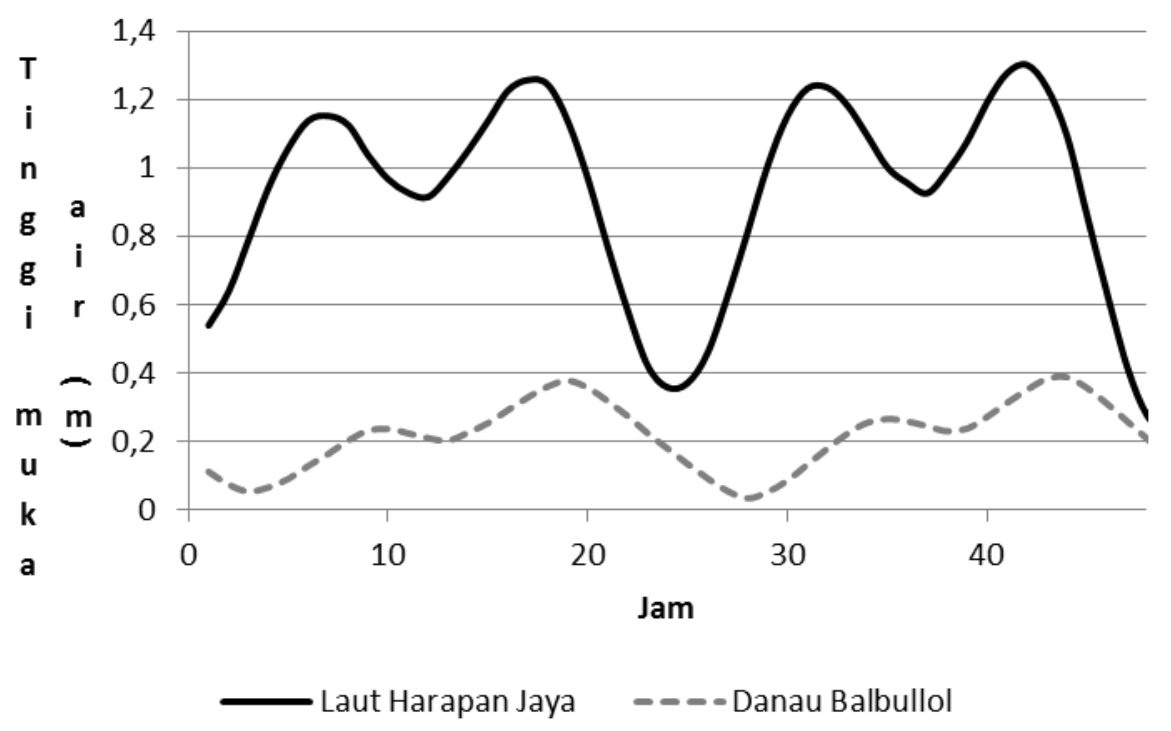

Gambar 9. Fluktuasi tinggi muka air dari logger muka air yang dipasang di kedalaman 2 $\mathrm{m}$ dan 3,5 m di Danau Balbullol dan Laut Desa Harapan Jaya. Data yang dipakai dari 8

Desember 2015 (08:00 AM) sampai 10 Desember 2015 (08:00 AM)

Di Danau Balbullol memperlihatkan jarak fase bulan kuarter akhir ke fase bulan penuh terjadi selama 6 hari 4 jam. Pada saat fase bulan penuh, air pasang terjadi 3 jam lebih lambat daripada laut (06:00), sedangkan air surut terjadi pada 14:00, lebih lama 4 jam daripada laut. Dari beberapa referensi Becking dkk. (2011), Colin (2009), Dawson dan Hamner (2005), Hamner dan Hamner (1998), Santodomingo (2009), penunandaan pasut di Balbullol lebih lama daripada beberapa danau di Palau, Vietnam, dan Berau. Waktu tunda pasut yang lebih lama ini tidak sebanding dengan jarak terdekat danau terhadap laut yang hanya 44,3 m, Tingkat komunikasi yang terbatas dengan laut, yakni hanya melalui pori dan lubang menjadikan air laut lebih lambat masuk ke danau.

Dari data 15 hari ini, jangkauan pasut di Danau Balbullol adalah 0,49 m dan nilai deviasi standar sejauh $0,11 \mathrm{~m}$. Mean amplitudo pasut adalah $0,39 \mathrm{~m}$, sedangkan di laut 1,58 m. Perbedaan mean amplitudo pasut Danau Balbullol dengan laut sangat signifikan, hanya $24 \%$ dari laut. Menurut penggolongan Becking (2011), Danau Balbullol tergolong danau yang memiliki tingkat isolasi yang tinggi karena pengurangan pasut melebihi $50 \%$ dari pasut laut. Demikian juga tertundanya pasut yang lebih dari dua jam.

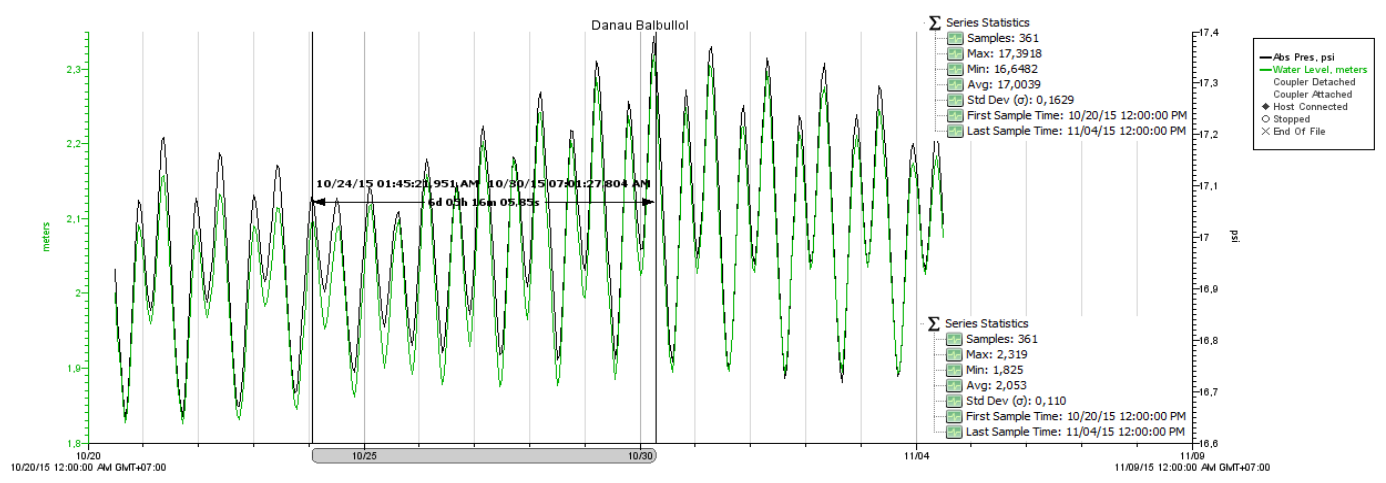

Gambar 10. Tinggi muka air Danau Balbullol dari 19 Oktober 2015 sampai 04 November 2015 


\section{Biota}

Terdapat dua jenis alga hijau yang hidup di danau, yakni Cladophora sp. dan Caulerpa lentifera yang hanya tumbuh di sebelah timurlaut. Tidak ditemukan alga di bagian lain danau. Moluska yang ditemui adalah koloni spesies bivalvia Brachidontes puniceus dan bulu babi Diadema setosum. Bulu babi ini hadir sebagai bagian dari ekosistem terumbu karang, yakni sebagai predator karang. Balbullol memang memiliki diversitas karang lunak yang tinggi. Ada minimal tujuh jenis karang lunak yang hidup di danau ini. Beberapa diantaranya banyak dan melimpah. Hidup juga tiga jenis karang keras, yakni Diploria strigrosa, Euphyllia glabrescens, Siderastrea siderea dengan kelimpahan sedang dan banyak. Bahkan dinding danau di bawah permukaan air ditumbuhi dengan bermacam-macam karang dan karang lunak. Di danau ini ditemukan banyak Lytocarpus sp. Substrat danau adalah karang mati dan pecahan cangkang Brachidontes spp. Gambar 11 di bawah memperlihatkan persentasi jenis-jenis biota di Danau Balbullol, yang kemudian diuraikan pada Tabel 2.

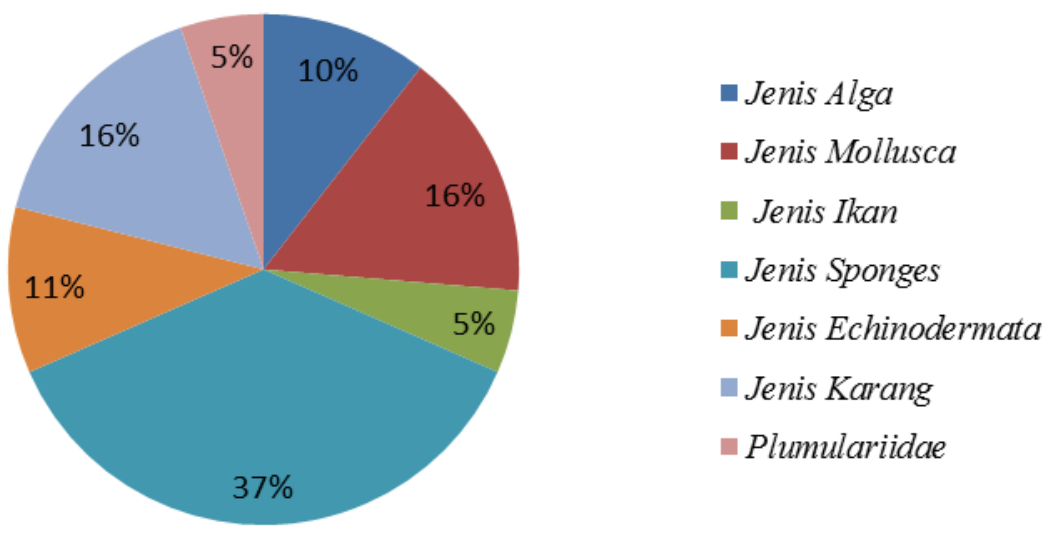

Gambar 11. Persentase jenis biota dari keseluruan biota di Danau Balbullol

Komposisi biota yang terdapat di danau laut belum dapat memperlihatkan secara jelas hubungan dengan tingkat keterisolasian danau tersebut. Situasi yang sama diungkapkan juga oleh Azzini dkk. (2007) yang meneliti Demosponges spesies di 15 tempat di Ha Long Bay Vietnam. Delapan diantaranya adalah danau laut. Demikian juga yang dilakukan oleh Becking dkk. (2011) di habitat anchialine Kalimantan timur dan Raja Ampat. Danau yang dianggap memiliki konektivitas sedang berdasarkan penggecilan amplitudo pasut, justru ditemukan spesies yang eksis di sistem yang terisolasi. Jenis karang lunak Suberites diversicolor yang hadir di danau terisolasi di Raja Ampat dan Kalimantan juga hadir di danau yang memiliki salinitas rendah dan suhu yang tinggi di
Ha Long Bay Vietnam. Spesies ini tidak hadir di Danau Balbullol yang amplitudo pasutnya $25 \%$ dan penundaan waktu pasut sampai empat jam dari laut. 
Tabel 2. Biota laut yang hidup di Danau Balbullol

\begin{tabular}{lclc}
\hline \multicolumn{1}{c}{ Biota } & Atribut & \multicolumn{1}{c}{ Biota } & Atribut \\
\hline Alga & & H. Plumulariidae & \\
Cladophora sp. & + & Lytocarpus sp. & +++ \\
Caulerpa lentifera & ++ & Sponges & \\
Moluska & & Cinachyrella alloclada & +++ \\
Brachidontes erosa & + & Paratetilla sp. & +++ \\
Brachidontes puniceus & + & Mycale armata & +++ \\
Pinctada sp. & ++ & Oceanapia sp. & ++++ \\
Karang & & Spongia officinalis & +++ \\
Diploria strigrosa & +++ & Theonella sp. & +++ \\
Euphyllia glabrescens & ++ & Zygomicale parishii & +++ \\
Siderastrea sidereal & ++ & Echinodermata & \\
Ikan & & Diadema setosum & +++ \\
Tylosurus sp. & + & Euapta godeffroyi & ++ \\
\hline
\end{tabular}

Keterangan : - absen, + sedikit, ++ sedang, +++ banyak, ++++ berlimpah

\section{KESIMPULAN}

Danau Balbullol adalah danau laut bertipe holomiktik dan terisolasi dari laut. Suhu dan salinitas air laut membentuk karakternya sendiri setelah masuk ke danau. Antara danau dan laut tidak terkoneksi dengan baik. Dengan demikian, danau ini adalah danau yang sangat sensitif karena sukar menetralisir kondisi di danau dengan ruang yang lebih luas (laut). Jikalau mendapat tekanan dari manusia ataupun alam, ekosistem di Danau Balbullol sangat mudah terganggu dan rusak.

\section{UCAPAN TERIMA KASIH}

Penelitian ini tidak akan terlaksana tanpa bantuan dari berbagai pihak. Terimakasih disampaikan kepada TNC Raja Ampat Marine Program, Wageningen University Netherland, BLUD Raja Ampat, mahasiswa FPIK UNIPA pengontrak matakuliah Tugas Akhir, dan tim yang sudah membantu di lapangan. Sebagian pendanaan penelitian dibiayai oleh Hibah Penerapan Produk Terapan 2016, Kementerian Riset Teknologi dan pendidikan Tinggi Republik Indonesia.

\section{DAFTAR PUSTAKA}

Azzini F, Calcinai B, Cerrano C, Bavestrello G, Pansini M. 2007. Sponges of the Marine Karst Lakes and of the Coast of the Islands of Ha Long Bay ( North Vietnam ). April 2003: 157-64.

Becking LE, de Leeuw C, Vogler C. 2014. Newly Discovered 'Jellyfish Lakes' in Misool, Raja Ampat, Papua, Indonesia. Marine Biodiversity 45(4): 597-98.

Becking LE, Renema W, Dondorp. 2009. Marine Lakes of Raja Ampat, West Papua, Indonesia: General Overview of First Sightings. Laporan Survei: 1-26.

Becking LE, Renema W, Santodomingo N, Hoeksema BW, Tuti J, Voogd de NJ. 2011. Recently Discovered Landlocked Basins in Indonesia Reveal High Habitat Diversity in Anchialine Systems. Hydrobiologia.

Cerrano C, Azzini F, Bavestrello G, Calcinai B, Pansini M, Sarti M, Thung D. 2006. Marine Lakes of Karst Islands in Ha Long Bay (Vietnam). Chemistry and Ecology 
22(6): 489-500.

Colin PL. 2009. Marine Enviroments of Palau. Sand Diego: Indo-Pacific Press.

Dawson MN, Hamner WM. 2003. Geographic Variation and Behavioral Evolution in Marine Plankton: The Case of Mastigias (Scyphozoa, Rhizostomeae). Marine Biology 143(6): 1161-74.

Dawson MN, Martin LE, Bell LJ, Patris S. 2009. Marine Lakes. In Encyclopedia of Islands, eds. R Gillespie and D.A Clague. Barkeley: Unversity California Press, 603-7.

Dawson MN, Martin LE, Penland LK. 2001. Jellyfish Swarms, Tourists, and the Christ-Child. Hydrobiologia 451: 131-44.

Hamner WM, Gilmer RW, Hamner PP. 1982. The Physical, Chemical, and Biological Characteristics of a Stratified, Saline, Sulfide Lake in Palau. Limnol. Oceanogr 27(5): 896-909.

Hamner WM, Hamner PP. 1998. Stratified Meromictic Lakes of Palau (Western Caroline Island). Physical Geography: 175-220.

Holthuis LB. 1973. Caridean Shrimps Found in Land-Locked Saltwater at Indo-West Pacific Localites Islands (Sinai Peninsua, Funafuti Atol, Maui and Hawaii Isalnds) With the Desription of One New Genus and Four New Spesies : 1-53.

Mangubhai S, Erdmann MV, Wilson JR, Huffard CL, Ballamu F, Hidayat NI, Hitipeuw C, Lazuardi M, Muhajir, Pada D, Purba G, Rotinsulu C, Rumetna L, Sumolang K, Wen W. 2012. Papuan Bird's Head Seascape: Emerging Threats and Challenges in the Global Center of Marine Biodiversity. Marine Pollution Bulletin 64(11): 2279-95. http://dx.doi.org/10.1016/j.marpolb ul.2012.07.024.
Purba GYS, Haryono E, Sunarto. 2017. Kapan Terbentuknya Danau Laut di Misool Raja Ampat? Prosiding Seminar Nasional Geografi UMS 2017, 22 Mei 2017. Fakultas Geografi Universitas Muhamadyah Surakarta. ISBN 978-602-361 072-3. hal. 655-662.

Santodomingo N. 2009. Unravelling the Moon Sponges: On the Ecology and Phylogeni of Cinchyrella Spp. and Paratetilla Spp. (Spirophorida: Tetillidae) in Indonesian Anchialine Lakes. Master Pro. Laiden University. 
